\title{
Comparison of the duration of the cell cycle in successive generation of synchronously dividing antheridial filaments of Chara vulgaris L. as measured with ${ }^{3} \mathrm{H}$ thymidine
}

\author{
M. GODLEWSKI AND M. J. OLSZEWSKA
}

\begin{abstract}
Laboratory of Plant Cytology and Cytochemistry, Institute of Biochemistry and Physiology, University of Lodz, Poland
\end{abstract}

(Received: April 21, 1972)

\begin{abstract}
Duration of the cell cycle in synchronously dividing cells of successive generation of antheridial filaments in Chara vulgaris L. was estimated on the basis of labeling with ${ }^{3} \mathrm{H}$ thymidine. Duration of the cell cycle is proportional to the volume of cells and with their decreasing in the consequence of consecutive divisions, the cell cycle becomes shorter. In the 2-, 4-, 8-, and 16-cell generations the length of the $\mathrm{S}$ period remains constant, so the duration of the $\mathrm{G}_{2}$ period is gradually reduced.
\end{abstract}

\section{INTRODUCTION}

In the succesive cell cycles of antheridial filaments in Chara vulgaris the dimensions of cells and nuclei decrease; during interphase the cells reach only $2 / 3$ of the volume of preprophase cells from previous generation. Investigations of the synthesis of nucleic acids and proteins during the cell cycles in the 4-, 8-, 16-, and 32-cell filaments reveal the beginning of DNA synthesis in telophase and its continuity in the early interphase. Incorporation of ${ }^{14}-\mathrm{C}-8$-adenine into RNA and ${ }^{3} \mathrm{H}$ phenylalanine to proteins in the succesive stages of interphase, calculated for $100 \mu^{2}$ of the area of nucleus and cytoplasm, is similar in all generations whereas the radioactivity estimated for one cell decreases proportionally to the reduction of the volume of nucleus and cytoplasm in consecutive generations (Olszewska and Godlewski 1972).

In the present paper we tried to examine whether a decrease of the cell growth and an intensity of synthesis of RNA and proteins in the succesive generations of antheridial filaments in Chara vulgaris has influence on the duration of the cell cycle and the $\mathbf{S}$ phase. 


\section{MATERIALS AND METHODS}

Antheridial filaments of Chara vulgaris L. were obtained from the material growing in the natural habitat (a pond in the village of Pelczyska, Lodz district).

The top portions of the thallus about $2 \mathrm{~cm}$ in length were incubated with $80 \mu \mathrm{Ci} / \mathrm{ml}(5 \mathrm{Ci} / \mathrm{mM})$ of ${ }^{3} \mathrm{H}$ thymidine (Amersham prod.) dissolved in the pond water. After 2 hrs of incubation (1:30 p.m. - $3: 30$ p.m.), a part of the material was fixed for $30 \mathrm{~min}$ in the mixture of abs. alcohol and ethanol $(3: 1)$. Most of the material was reincubated again for 15, 20, 25, 30 and $35 \mathrm{hrs}$ in pond water free of nonradioactive thymidine, because the high concentration of thymidine may disturb the normal cell cycle. A previous elementary experiments have revealed a lack of the labeled mitoses in all generations of antheridial filaments after $5 \mathrm{hrs}$ of postincubation. The antheridial filaments were squeezed out onto microslides. The preparations were coated with Ilford L 4 emulsion and exposed for 6 months. After developing procedure the autoradiograms were stained with Unna's mixture.

Only the filaments with completely synchronous cell cycle were taken for analysis. A generation dominating in the antheridium was considered in calculations.

\section{RESULTS}

In order to observe the growth of cells in antheridial filaments after succesive periods of postincubation, the length of cells with intensively labeled nuclei, i.e. when the individual silver grains were undistinguishable, was measured (cf. Plate I and II). They were the cells synthesizing DNA (S phase) during whole incubation time, so their nuclei could use maximaly ${ }^{3} \mathrm{H}$ thymidine. The cells labeled mean or poorly were at the end of the $\mathrm{S}$ phase when ${ }^{3} \mathrm{H}$ thymidine was available, or they were entering the $\mathrm{S}$ phase at the end of incubation or immediately after removal of radioactive precursor and they used a pool of free ${ }^{3} \mathrm{H}$ thymidine present in the cells, antheridia and other parts of thallus.

The length of cells with strongly labeled nuclei after succesive periods of postincubations demonstrates Text-fig. 1. Several points of this diagram were made on the basis of average calculation from 6 to 67 filaments or most frequently from 40 to 50 filaments. As indicates the diagram, a maximal length reach the cells from 32-cell filaments in the shortest time $20 \mathrm{hrs}$ of postincubation. Younger filament generations consisted of the longer cells attain the maximal length later; in 16-cell generation after $25 \mathrm{hrs}$ of postincubation; in 8-cell 
generation after $30-35 \mathrm{hrs}$; and in 4-cell generation most of the cells after $35 \mathrm{hrs}$; the cells of 2-cell filaments have not reached the dimensions of preprophase cells after $35 \mathrm{hrs}$ of postincubation.

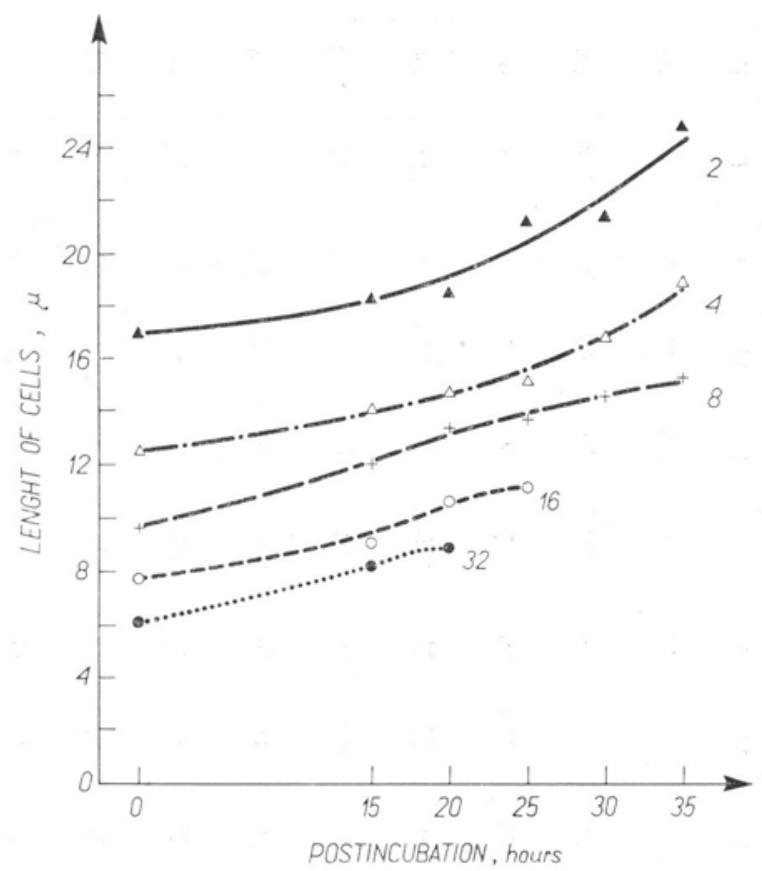

Text-fig. 1. The growth of cells of particular generations of antheridial filaments in Chara vulgaris with strongly labeled nuclei after 2 hrs of incubation with ${ }^{3} \mathrm{H}$ thymidine in consecutive periods of postincubation; 2-, 4-, 8-, 16, and 32-, number of cells in filament.

The cells from succesive generations of antheridial filaments with nuclei maximaly labeled after $2 \mathrm{hrs}$ of postincubation with ${ }^{3} \mathrm{H}$ thymidine and after a particular periods of postincubation are inserted in Table I and II. Enclosed microphotographs show that the more older generation of antheridial filaments the more faster its cells with strongly labeled nuclei enter mitosis. The cells of 64-cell filaments formed by the division of 32-cell filaments have transformed into spermatozoa; the first stages of spermatogenesis are presented in Plate II, figs. 14 and 15 .

A few cells with intensively labeled nuclei were seen also after longer time of postincubation. They were only a small part of investigated population - with extended - in comparison to typical for define generation - cell cycle. In the 8-cell generation after $35 \mathrm{hrs}$ of postincubation only 15 filaments with a prolonged cell cycle were found in contrary to 47 after $30 \mathrm{hrs}$; and in 16-cell generation 5 fila- 


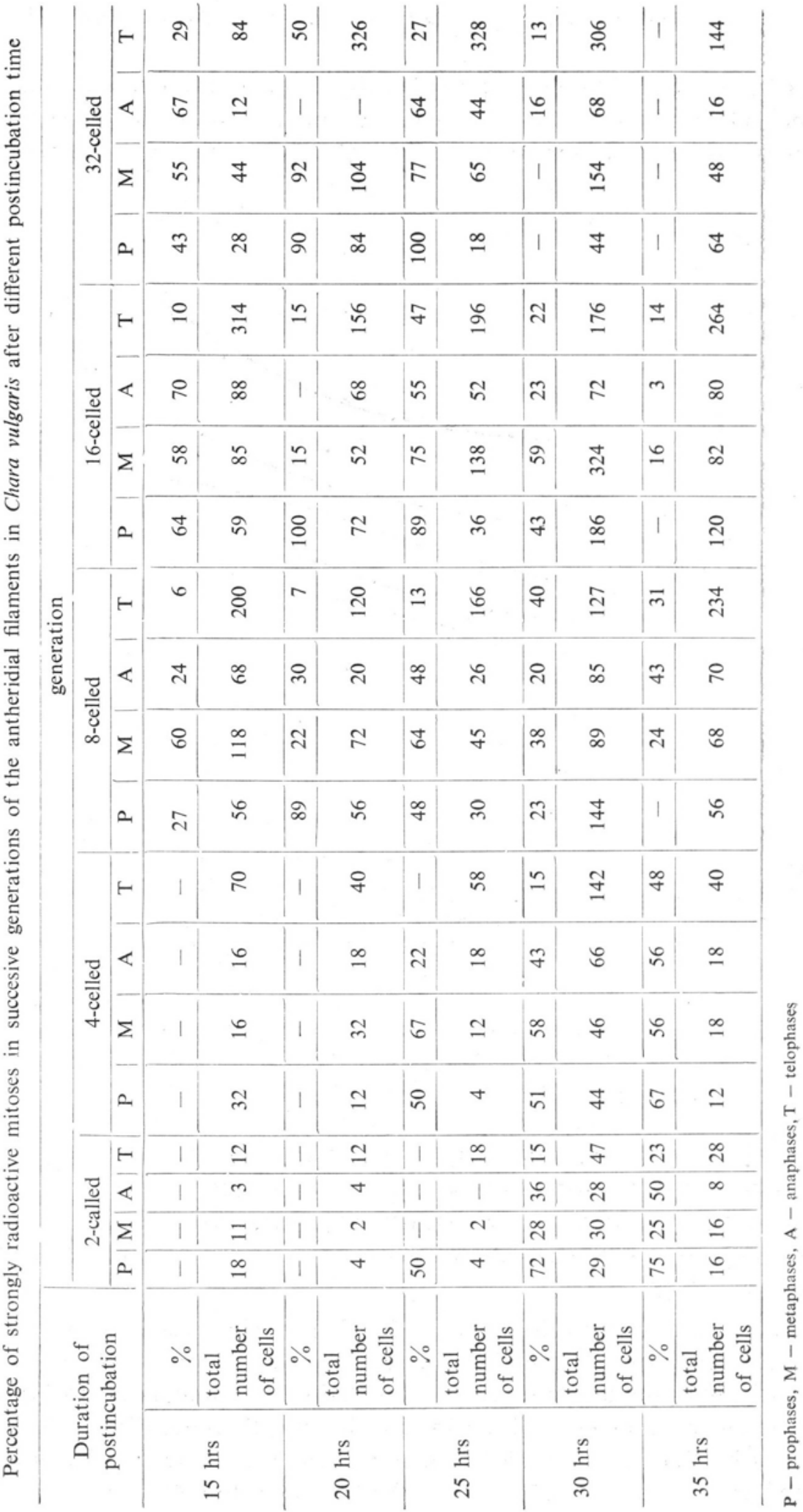


ments in the presence of 23 after $25 \mathrm{hrs}$. It is noteworthy that in the 8 -cell generation the cells with strongly labeled nuclei after $35 \mathrm{hrs}$ of postincubation have reached larger dimensions than typical for preprophase in that generation. Similarly, as in the case of analysis of the growth of cells with radioactive nuclei, in the calculation of labeled mitosis only mitotic figures strongly labeled were taken (Plate II, figs. $4,5,6,11,12,13)$.

A percentage of radioactive mitoses (Table 1) was calculated with reference to all mitotic figures, i.e. mean (Plate II, fig. 6), poorly radioactive (Plate II, fig. 7) or non-radioactive completely. The percentage of radioactive mitosis with intensively-labeled chromosomes in the ratio to labeled mean, poorly or non-radioactive in individual generations of antheridial filaments after consecutive times of postincubation is presented in Table 1.

Table 1 indicates, that the maximum of intensively labeled mitoses appears more earlier than older is the generation of antheridial filaments. A main wave of strongly labeled prophases precedes the maximal

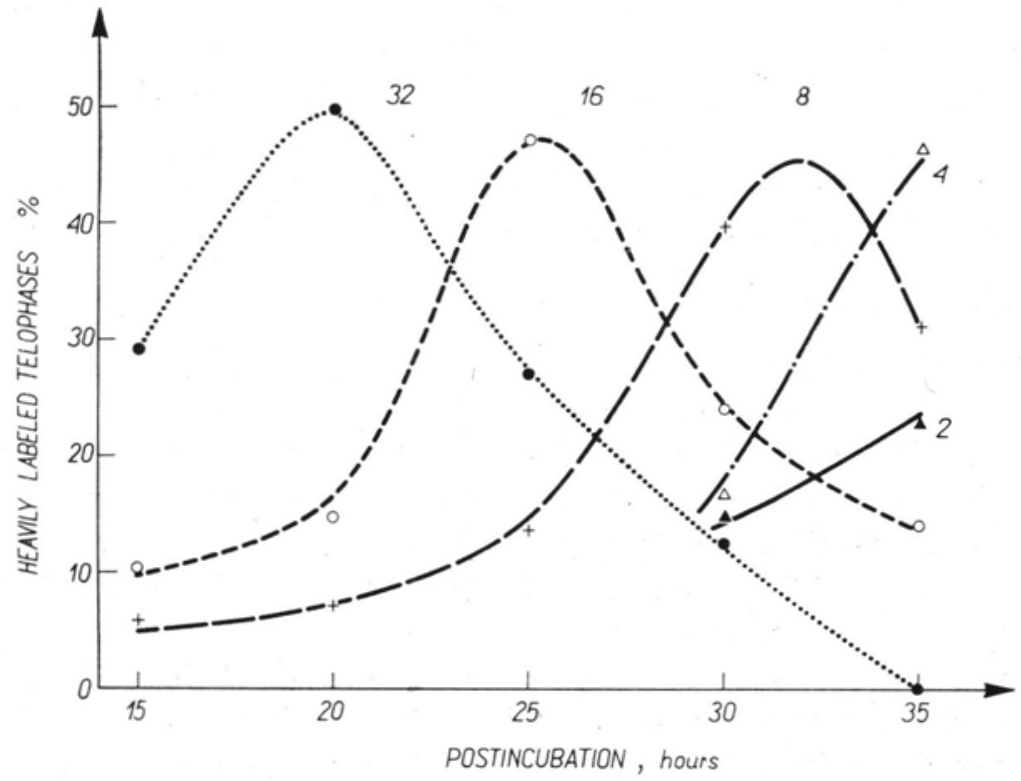

Text-fig. 2. Percentage of strongly labeled telophases at various times of postincubation in succesive generations of antheridial filaments in Chara vulgaris; $2-, 4-, 8-, 32,-$ number of cells in filament.

rise of intensively labeled telophases. A drop in number of radioactive telophases is preceded by a decrease of strongly radioactive earlier stages of mitosis.

To estimate the duration of the cell cycle, i.e. from telophase initiating a consecutive population until the next telophase, when one 
generation finishes, the strongly labeled telophases were chosen as a determinant. In antheridial filaments the $\mathrm{S}$ phase begins in telophase, i.e. simultaneously with the new cell cycle (Olszewska and Godlewski, 1972) and therefore, an interval between the beginning of incubation with ${ }^{3} \mathrm{H}$ thymidine and the appearance of the next strongly labeled telophases established exact duration of cell cycle. The diagram (Text-fig. 2) made on the basis of the data inserted in Table 1 demonstrates, that after $2 \mathrm{hrs}$ of incubation with ${ }^{3} \mathrm{H}$ thymidine most (about 50\%) of strongly labeled telophases appear in 8-cell generation after approximately $32 \mathrm{hrs}$ of postincubation; in 4-cell generation after $35 \mathrm{hrs}$; in 2-cell generation $50 \%$ of radioactive telophases is not reached after $35 \mathrm{hrs}$ of postincubation. Following the maximum of strongly labeled telophases the fall appears especially visible in the 8-, 16-, and 32-cell generation.

After $30 \mathrm{hrs}$ of postincubation only $40 \%$ of intensively labeled telophases occured in 8-cell filaments and $31 \%$ after 35 hrs. Because in $16-$, and 32-cell filaments the strongly labeled telophases have reached $50 \%$ we can assume that the maximum of such telophases in 8-cell filaments would be between 30 and $35 \mathrm{hrs}$ of postincubation.

On the basis of the observations of 4-cell filaments with strongly labeled nuclei, the maximum of strongly labeled telophases might be expected after the time longer than $35 \mathrm{hrs}$, because after $35 \mathrm{hrs}$ a large number of labeled interphases nuclei has still been found. Moreover, Text-fig. 1 shows that a considerable part of cell population with intensively labeled nuclei in 4-cell generation does not reach the preprophase dimensions after $35 \mathrm{hrs}$ of postincubation. In 2-cell generation after $35 \mathrm{hrs}$ of postincubation only $23 \%$ of strongly labeled telophases occurs. On the basis of these results and by an analogy to data obtained for an older generation of antheridial filaments could be assumed, that the cell cycle in 2-cell generation lasts about 40-50 hrs.

In the antheridial filaments of Chara vulgaris the beginning of the cell cycle and the $\mathrm{S}$ phase are in coincidence. Therefore, in estimation of duration of the cell cycle must be considered $2 \mathrm{hrs}$ of incubation with ${ }^{3} \mathrm{H}$ thymidine, because the cells being in the $\mathrm{S}$ phase could maximally use the radioactive precursor and in consequence strongly labeled, have entered the cell cycle in that time.

As indicate Text-figs. 1 and 2, in majority of the cells in 32-cell filaments the generation time lasts $2+$ about $20 \mathrm{hrs}$; in 16-cell filaments $-2+$ about $25 \mathrm{hrs}$; in 8 -cell $-2+32 \mathrm{hrs}$; in 4-cell filaments $-2+$ a little more than $35 \mathrm{hrs}$; and in 2-cell filaments $2+$ much more than $35 \mathrm{hrs}$.

Duration of the $\mathrm{S}$ phase may be estimated by multiplying the frequency of cells labeled after a short incubation with ${ }^{3} \mathrm{H}$ thymidine by the average generation time (Monesi 1969). The frequency of 
nuclei labeled with ${ }^{3} \mathrm{H}$ thymidine in 2-, 4-, 8-, and 16-cell generation after $2 \mathrm{hrs}$ of incubation, the average generation time in the particular generations and a resulting from these data duration of the $\mathrm{S}$ phase are presented in Table 2 .

Table 2

Duration of the $\mathrm{S}$ phase in succesive generations of antheridial filaments in Chara vulgaris

\begin{tabular}{l|c|c|c|c}
\hline \multicolumn{1}{c|}{ Generation } & 2-celled & 4-celled & 8-celled & 16-celled \\
\hline Frequency of nuclei labeled & $32 \%$ & $37 \%$ & $51 \%$ & $54 \%$ \\
\hline Mean duration of cell cycle, hrs & 50 & 40 & 34 & 27 \\
\hline Duration of S period, hrs & 16 & 15 & 17 & 15 \\
\hline
\end{tabular}

The duration of the S phase in 2-, 4-, 8-, and 16-cell generation in antheridial filaments is approximately similar what supports previous results (Olszewska and Godlewski, 1972; Text-fig. 4). The filaments of 32-cell are the last generation of dividing cells. It seems probable, that a large asynchrony of the cell cycles in particular filaments of one antheridium almost disappears during the last cell cycle, because the processes of spermatogenesis take place parallely in all filaments of antheridium. Sometimes, the antheridia were noticed with about one half of 64-cell and 32-cell filaments and their cells were in preprophase and division stages. In these phases there is no DNA synthesis and adding of these 32-cell filaments as non-radioactive ones causes a considerable decrease of percentage of labeled cells in the generation.

The rejection of the cells described above given the reverse results. Therefore, determination of percentage of the ${ }^{3} \mathrm{H}$ thymidine labeled cells after $2 \mathrm{hrs}$ of incubation was impossible for 32-cell generation. The radioactivity of nuclei after $2 \mathrm{hrs}$ of incubation with ${ }^{3} \mathrm{H}$ thymidine in 32-cell generation, as a function of the dimensions of cells, reveals that DNA synthesis occupies a larger part of the cell cycle than in younger generation (Olszewska and Godlewski, 1972; Text-fig. 4).

The estimated duration of this $\mathrm{S}$ phase in the 2-, 4-, 8-, and 16-cell generation maybe too high, because of ${ }^{3} \mathrm{H}$ thymidine incubation time (1:30 p.m. - 3:30 p.m) i.e. when in all generations of antheridial filaments in Chara vulgaris a maximum of mitotic activity has reached about 40\% (Godlewskil and M a ciejewska 1972). Because the $\mathrm{S}$ phase starts in telophase, more cells incorporated ${ }^{3} \mathrm{H}$ thymidine than could be expected e.g. at 5:00 a.m. - 7:00 a.m., when the mitotic activity is low - only a few $\%$. 


\section{EXPLICATIONS OF FIGURES}

\section{Plate I}

Antheridial filaments in Chara vulgaris from 2-, 4-, and 8-cell generation with intensively labeled nuclei after $2 \mathrm{hrs}$ of incubation with ${ }^{3} \mathrm{H}$ thymidine and various periods of postincubation $\times 1000$.

Figs. 1-6. 2-cell generation; 1 - telophase in 1-cell filament immediately after incubation with ${ }^{3} \mathrm{H}$ thymidine; 2 - interphase, 15 hrs postincubation; 3 - interphase, 20 hrs postincubation; 4 - interphase, $25 \mathrm{hrs}$ postincubation; 5 - interphase, 30 hrs postincubation; 6 - interphase, 35 hrs postincubation.

Figs. 7-12. 4-cell generation; 7 - telophase in 2-cell filaments immediately after incubation with ${ }^{3} \mathrm{H}$ thymidine; 8 - interphase, 15 hrs postincubation; 9 - interphase, $20 \mathrm{hrs}$ postincubation; 10 - interphase, $25 \mathrm{hrs}$ postincubation; 11 - interphase, $30 \mathrm{hrs}$ postincubation; 12 - radioactive telophase, 35 hrs postincubation.

Figs. 13-18. 8-cell generation; 13 - telophase in 4-cell filament immediately after incubation; 14 - interphase, $15 \mathrm{hrs}$ postincubation; 15 - interphase, $20 \mathrm{hrs}$ postincubation; 16 - interphase, $25 \mathrm{hrs}$ postincubation; 17 - radioactive anaphases, $30 \mathrm{hrs}$ postincubation; 18 - radioactive telophases, $35 \mathrm{hrs}$ postincubation.

\section{Plate II}

Antheridial filaments in Chara vulgaris from 16-, 32-, and 64-cell generation with intensively labeled nuclei after $2 \mathrm{hrs}$ of incubation with ${ }^{3} \mathrm{H}$ thymidine and various periods of postincubation; $\times 1000$.

Figs. 1-8. 16-cell generation; 1 - telophase in 8-cell filament immediately after incubation with ${ }^{3} \mathrm{H}$ thymidine; 2 - interphase, $15 \mathrm{hrs}$ postincubation; 3 - interphase, 20 hrs postincubation; 4 - radioactive metaphases, 25 hrs postincubation; 5 - radioactive anaphases, $25 \mathrm{hrs}$ postincubation; 6 - intensively labeled telophases, $25 \mathrm{hrs}$ postincubation; 7 - mean labeled telophases, $25 \mathrm{hrs}$ postincubation; 8 - poorly labeled telophases, 25 hrs postincubation.

Figs. 9-13. 32-cell generation; 9 - telophase in 16-cell filament immediately after $2 \mathrm{hrs}$ postincubation with ${ }^{3} \mathrm{H}$ thymidine; 10 - interphase, $15 \mathrm{hrs}$ postincubation; 11 - intensively labeled metaphases, 20 hrs postincubation; 12 - intensively labeled anaphases, $20 \mathrm{hrs}$ postincubation; 13 - strongly labeled telophases, $20 \mathrm{hrs}$ postincubation.

Figs. 14-15. 64-cell generation with nuclei intensively labeled with ${ }^{3} \mathrm{H}$ thymidine in a consequence of $2 \mathrm{hrs}$ incubation of 32 -cell generation being in that time in the $\mathrm{S}$ phase; 14 - after $25 \mathrm{hrs}$ postincubation; $15-35 \mathrm{hrs}$ postincubation; cells in fig. 15 are in later stage of spermatogenesis than the cells from fig 14. 





Plate II

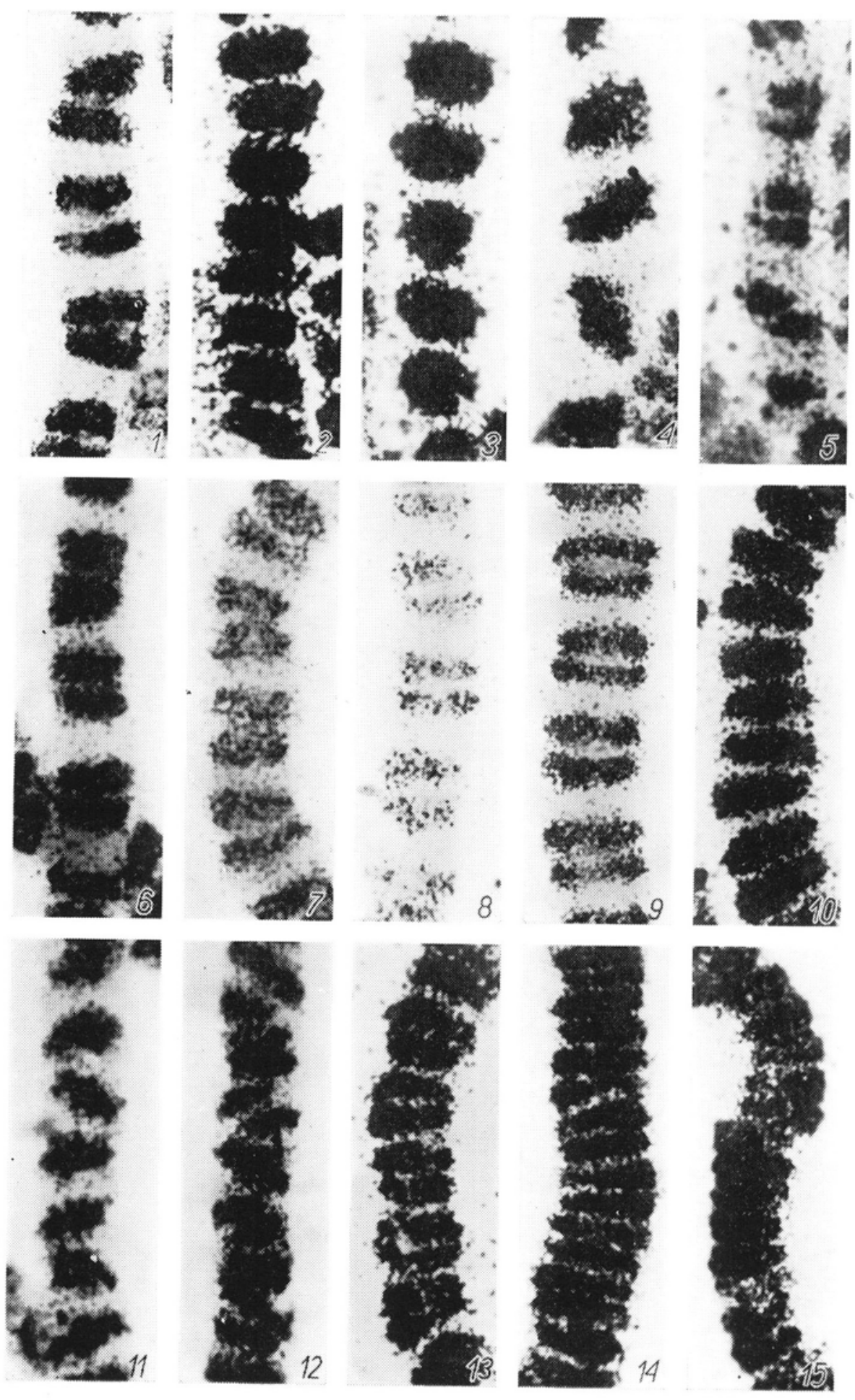


It is necessary to stress, that incorporation of ${ }^{3} \mathrm{H}$ thymidine into nuclei is continued a certain time after withdrawal of this precursor, because in material fixed after postincubation labeling was higher than immediately after incubation. Therefore, the $\mathbf{S}$ phase lasts longer than $2 \mathrm{hrs}$ (cf. Plate I, figs. 1 and 2, figs. 7 and 8).

Apart from an absolute time of duration of the $\mathrm{S}$ phase, the results discussed above suggest, that a shorten of the cell cycle in succesive generation of antheridial filaments in Chara vulgaris takes place mainly by the shorten of the $G_{2}$ phase.

\section{DISCUSSION}

Undoubtedly, in interpretation of the results too long incubation of the material with ${ }^{3} \mathrm{H}$ thymidine must be considered. However, the nuclei of antheridial filaments uptake the nucleosides with difficulty (Olszewska and Godlewski 1972). Thereby, a shorter incubation may excess the radioactive dose, safe for the cells, or longer more than 1 year exposition might cause an appearance of excessive background. Tests with ${ }^{3} \mathrm{H}$ thymine gave no hopefull results.

The calculations of duration of the $\mathrm{S}$ phase indicate, that the incubation with ${ }^{3} \mathrm{H}$ thymidine last approximately $1 / 8$ of this phase, as short as in similar experiments of other authors.

In spite of our presumptions, in an homogenous population of synchronously dividing cells of antheridial filaments of one generation in Chara vulgaris, the duration of the cell cycle is variable. Information concerning the variability of duration of $G_{2}$ and $G_{1}$ gives a curve illustrating the number of mitoses labeled in an particular period of postincubation. The more faster this curve rises, or falls the more shorter is the duration of $G_{2}$ or $G_{1}$ (Monesi, 1969). Distribution of frequency of telophases labeled in particular periods of postincubation in antheridial filaments of Chara vulgaris shows a high variability of the $\mathrm{G}_{2}$ interval; in the 8-, 16-, and 32-cell generation the variability can reach several hours, and it seems to be higher in younger generation, i.e., where $\mathrm{G}_{2}$ lasts longer.

It is well known that duration of the cell cycle is changeable even in the same population (ref. Mones i 1969). Socher and Davids on (1970) have described two populations of cells during the development of the lateral roots in Vicia faba. One of them consisting of $84 \%$ of all cells has divided very quickly - the duration of $G_{2}$ and $1 / 2$ of mitosis lasts $3.3 \mathrm{hrs} .16 \%$ of cells represent the population slowly dividing, the $\mathrm{G}_{2}$ phase lasts $12 \mathrm{hrs}$ longer. 
According to the results mentioned above, the presence of two different populations maybe associated with morphogenesis, but such explanation of variability of generation time in the cells of antheridial filaments of the same generation is useless. In binucleated cells of root meristem in Allium cepa formed after treatment with coffein, the $\mathrm{G}_{2}$ lasts 3-6 hrs (Gonzále z-Fernánde z et al., 1971).

Various generation time in one generation of antheridial filaments in Chara vulgaris may cause asynchronic divisions described in these cells in Charophyta by Teleżyński (1929) and also in Chara vulgaris by Olszewska and Godlewski (1972). A fluctuation of generation time may be caused by a factor regulating the 24-hours rhythm (diurnal) of mitotic activity. In antheridial filaments of Chara vulgaris 2-3 peaks of mitotic activity were found during $24 \mathrm{hrs}$ and also the periods of much lower mitotic activity (Godlewski and

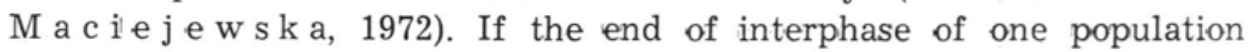
of cells will be at the time of lower mitotic activity, a part of its may enter mitosis before, and another part after this time. In the situation, when a maximum of mitotic activity shows a rhythm another than every $24 \mathrm{hrs}$, and knowing the generation time of cells of given generation, it is possible to estimate roughly a time of appearance of next division, starting from the main peak of mitotic activity at 10:00 a.m. 2:00 p.m. These hours are in coincidence with experimentally described consecutive peaks of mitotic activity during $24 \mathrm{hrs}$ (Godlewski and $\mathrm{M} \mathrm{a} \mathrm{ciejew} \mathrm{s} \mathrm{a} \mathrm{1972).}$

The diurnal rhythm of mitotic activity, in consequency of which a small or larger number of cells is in the S phase, has strong influence on the number of cells incorporating ${ }^{3} \mathrm{H}$ thymidine and on the estimation on this basis of the duration of the $\mathrm{S}$ phase. In these investigations cannot be omitted the diurnal rhythm of mitotic activity.

A dependence of duration of the cell cycle on the dimensions of cells containing the same amount of DNA has not been studied yet. A proportional dependence of duration of the cell cycle on the content of DNA has been indicated by Van't Hof and Sparrow (1963) in the 6 species of Angiospermae. The cells with the high amount of DNA are usually larger than of the plants with low content of nuclear DNA, therefore, the conclusion maybe drawn, that dimensions of cells characteristic for given species have influence on the duration of the cell cycle in that experimental case. It seems to be interesting a correlation between duration of the cell cycle and dimensions of cells with the same DNA content in successive generations of antheridial filaments in Chara vulgaris. Since the time of the $\mathrm{S}$ phase in the 2-, 4-, 8-, and 16-cell generation maybe considered as constant and lasts about $15 \mathrm{hrs}$, then the $\mathrm{G}_{2}$ lasts approximately $35 \mathrm{hrs}$ in 2-cell filaments; about $25 \mathrm{hrs}$ in 4-cells; about $19 \mathrm{hrs}$ in 8-cells; about $12 \mathrm{hrs}$ in 16-cell filaments. 
A decrease of length of $\mathrm{G}_{2}$ proportional to the reduction of volume of cells is correlated with decrease of synthesis of RNA and proteins during interphase in succesive generations of cells of antheridial filaments (Olszewska and Godlewski 1972).

\section{REFERENCES}

Godlewski M., Maciejewska E., 1972, Rytm dobowy aktywności mitotycznej w synchronicznie dzielących się niciach spermatogenicznych Chara vulgaris L., Postępy Astron., Biull. Specj., Warszawa.

González-Fernández A., Gi ménez-M artin G., Diéz J. L., de 1 a Torre C., López-Sá e z J. F., 1971, Interphase development and beginning of mitosis in the different nuclei of polynucleate homocaryotic cells, Chromosoma 36: 100-111.

M o nesi V., 1969, DNA, RNA and proteins during the mitotic cycle [in:] Handbook of Molecular Cytology, A. Lima-de-Faria ed., North-Holland Publ. Comp., Amsterdam-London.

Olszewska M. J., Godlewski M., 1972, Autoradiographic study of the synthesis of nucleic acids and proteins during the cell cycle of synchronously dividing antheridial filaments in Chara vulgaris L., Folia Histochemica et Cytoch. 10: 245-256.

Socher S. H., Davids on D., 1970, Heterogeneity in $\mathrm{G}_{2}$ duration during lateral root development, Chromosoma 31: 478-484.

Teleżyński H., 1929, Garnitures des chromosomes et synchronisme des divisions dans les filaments d'antherozoïdes chez certaines espèces du genre Chara Vaill., Acta Soc. Bot. Pol. 6: 230-247.

Van't Hof J., Sparrow A. H., 1963, A relationship between DNA content, nuclear volume and minimum mitotic cycle time, Proc. Natl. Ac. Sci. 49: $897-902$.

Porównanie przy pomocy tymidiny ${ }^{3} \mathrm{H}$ czasu trwania cyklu życiowego komórek kolejnych pokoleń dzielacych się synchronicznie nici spermatogenicznych Chara vulgaris $\mathrm{L}$.

\section{Streszczenie}

Przy użyciu tymidiny ${ }^{3} \mathrm{H}$ obliczono czas trwania cyklu życiowego synchronicznie dzielących się komórek kolejnych pokoleń nici spermatogenicznych Chara vulgaris. Czas trwania cyklu życiowego jest wprost proporcjonalny do objętości komórek i wraz z ich zmniejszaniem po kolejnych podzialach cykl życiowy ulega skróceniu. W pokoleniach 2-, 4-, 8-, i 16-komórkowych nici czas trwania fazy S jest stały, a więc stopniowej redukcji ulega czas trwania fazy $\mathrm{G}_{2}$.

Zakład Cytologii $i$ Cytochemii Roślin

Instytut Biochemii $i$ Fizjologii

Uniwersytetu Łódzkiego 